\title{
Dampak belanja irigasi dan jaringan terhadap output PDRB sektor pertanian dan pertumbuhan ekonomi Kota Jambi
}

\author{
Siti Aminah; Parmadi* \\ Prodi Ekonomi Pembangunan Fakultas Ekonomi dan Bisnis Universitas Jambi \\ *E-mail korespodensi: parmadi68pc@gmail.com
}

\begin{abstract}
This study aims to analyze the development of irrigation and network expenditure and the development of GDP output in the agricultural sector of the city of Jambi during the period 2005-2015 and analyze the effect of irrigation and network spending on GDP Output in the agricultural sector and economic growth in Jambi City. The results of the study showed that during the study period of 2005-2015 with an average growth of $61.98 \%$, the average value of GRDP at the price of Jambi City was 157,601.68 in million rupiahs with an average growth of $13.67 \%$ and the lowest growth occurred in 2006 at $6.60 \%$. Based on the regression results, the results show that the first model of irrigation and network expenditure has a positive and significant effect on the GRDP of the agricultural sector while in the second model irrigation and network expenditure has no significant effect on economic growth.
\end{abstract}

Keywords: Irrigation and Network Expenditure, Agricultural Sector GRDP, Economic Growth.

\begin{abstract}
Abstrak
Penelitian ini bertujuan untuk menganalisis perkembangan Belanja irigasi dan jaringan serta perkembangan output GDP sektor pertanian Kota Jambi selama periode tahun 2005-2015 dan menganalisis pengaruh belanja irigasi dan jaringan terhadap GDP Output sektor pertanian dan pertumbuhan ekonomi Kota Jambi. Hasil penelitian menunjukkan Selama periode penelitian tahun 2005-2015 dengan rata-rata pertumbuhan $61,98 \%$, nilai rata-rata PDRB harga berlaku Kota Jambi sebesar 157.601,68 dalam juta rupiah dengan rata-rata pertumbuhan sebesar $13,67 \%$ dan pertumbuhan PDRB harga berlaku Kota Jambi tertinggi pada tahun 2011 yakni 38,26\% dan pertumbuhan terendah terjadi pada tahun 2006 yakni 6,60\%. Berdasarkan hasil regresi diperoleh hasil bahwa pada model pertama belanja irigasi dan jaringan berpengaruh positif dan signifikan terhadap PDRB sektor pertanian sementara dan pada model kedua belanja irigasi dan jaringan tidak berpengaruh signifikan terhadap pertumbuhan ekonomi.
\end{abstract}

Kata kunci: Belanja irigasi dan jaringan, PDRB sektor pertanian,Pertumbuhan ekonomi

\section{PENDAHULUAN}

Kota Jambi adalah salah satu Kota yang terdapat di Provinsi Jambi dan sekaligus merupakan pusat atau lokasi pemerintah Provinsi Jambi, karena Kota Jambi adalah Kota pertama dan yang paling tua di Provinsi Jambi maka jumlah penduduknya pun lebih padat jika dibandingkan dengan wilayah kabupaten atau Kota yang berada di Provinsi Jambi, dengan tingkat pembangunan yang lebih maju maka kegiatan ekonomi di Kota Jambi termasuk yang mengalami kemajuan yang pesat dengan semakin meningkatnya pembangunan infrastruktur hal ini tidak terlepas dari peran pemerintah Kota Jambi yang giat membangun dan memberikan pelayanan kepada masyarakat Kota Jambi dengan menggunakan anggaran belanja daerah Kota Jambi. Dari data komponen belanja tidak 
langsung pemerintah Kota Jambi selama periode tahun 2005 sampai tahun 2015 ratarata proporsi anggaran yang lebih besar adalah belanja gedung dan bangunan sebesar $6,95 \%$ dan disusul oleh belanja jalan sebesar 5,15\% kemudian belanja peralatan dan mesin dengan rata-rata sebesar 3,74\% dan belanja modal lainnya $1,89 \%$ dan belanja irigasi jaringan sebesar $1,70 \%$ terakhir yang terendah adalah belanja tanah yakni dengan rata-rata sebesar $0,75 \%$.

Walaupun belanja irigasi dan jaringan proporsinya lebih kecil namun jika dilihat sektor pertanian di Kota Jambi masih memberikan kontribusi terhadap Produk Domestik Regional Bruto (PDRB) Kota Jambi pada tahun 2012 sebesar 194,9 milyar dan meningkat pada tahun 2013 menjadi 223,4 milyar maka belanja irigasi dan jaringan masih berpotensi untuk meningkatkan output ektor pertanian tersebut dan pertumbuhan ekonomi Kota Jambi pada akhirnya. Berdasarkan uraian pada latar belakang diataslah yang melatar belakangi penulis untuk menganalisis dampak belanja irigasi dan jaringan terhadap output PDRB sektor pertanian dan pertumbuhan ekonomi Kota Jambi. Secara spesifik perumusan permasalahan penilitian ini adalah bagaimanakah perkembangan, belanja irigasi dan jaringan serta output (PDRB) sektor pertanian di Kota Jambi selama periode tahun 2005 sampai 2015, dan bagaimana pengaruh Belanja irigasi dan Jaringan terhadap output (PDRB) sektor pertanian dan pertumbuhan ekonomi Kota Jambi.

\section{METODE}

\section{Metode analisis}

Dalam menganalisa data-data yang diperoleh untuk menjawab tujuan dari penelitian ini, maka digunakan metode-metode analisa sebagai berikut:

1. Analisis Deskriptif

Merupakan analisis yang dilakukan secara deskriptif untuk memberikan gambaran mengenai perkembangan Variabel-variabel Penelitian, digunakan formula sebagai berikut:

Igt $=\frac{\text { It }- \text { It }-1}{\text { It-1 }} \times 100 \%$

Dimana:

$\overline{\text { Igt }}=$ Perkembangan Variabel-variabel Penelitian (Belanja irigasi dan Jaringan dan Output sektor pertanian)

It $=$ Variabel Penelitian tahun $\mathrm{t}$

It-1 = Variabel Penelitian tahun $\mathrm{t}-1$

2. Analisis Kuantitatif

Kemudian untuk menganalisis pengaruh Input (Tenaga kerja) sektor pertanian terhadap Konsumsi Pemerintah Indonesia digunakan regresi sederhana sebagai berikut :

$\mathrm{Y}=\boldsymbol{\beta} 0+\boldsymbol{\beta}_{1} \mathrm{~B}+\mathrm{e}$

$\mathrm{Y}=$ PDRB Sektor pertanian

Bo $\quad=$ Konstanta

$\beta \mathrm{i}=$ Koefisien regresi

$\mathrm{B}=$ Belanja irigasi dan jaringan

$\mathrm{e}=$ error disturbance

$\mathbf{G}=\boldsymbol{\beta} \mathbf{0}+\boldsymbol{\beta}_{1} \mathbf{B}$

$\mathrm{G} \quad=$ Pertumbuhan ekonomi

Bo $\quad=$ Konstanta

$\beta \mathrm{i}=$ Koefisien regresi

$\mathrm{B} \quad=$ Belanja irigasi dan jaringan

$\mathrm{e}=$ error disturbance 


\section{Uji Hipotesis}

Untuk melihat apakah koefisien signifikasi atau tidak, maka dilakukan uji dengan alat uji sebagai berikut:

\section{Uji T}

Uji ini digunakan untuk mengetahui secara parsial seberapa besar pengaruh tingkat signifikasi variabel bebas (independent) terhadap variabel terikat (dependent). Uji hipotesis dirumuskan sebagai berikut:

Ho : $\beta=0$------ artinya tidak terdapat pengaruh yang signifikan variabel $X$ terhadap variabel $\mathrm{Y}$

Ho : $\beta \neq 0$------ artinya terdapat pengaruh yang signifikan variabel $\mathrm{X}$ terhadap variabel $\mathrm{Y}$

Nilai t hitung dapat diperoleh dengan rumus sebagai berikut :

$$
\text { t.hit }=\frac{\beta . i}{S \beta . i}
$$

Dimana :

$\beta \mathrm{i}=$ Koefisien Regresi

$\mathrm{S} \beta \mathrm{i}=$ Standar deviasi dari $\beta \mathrm{i}$

Nilai t hitung selanjutnya dibandingkan dengan $t$ tabel pada derajat kebebasan (df) dengan tingkat keyakinan tertentu dengan keputusan sebagai berikut :

T hitung $>$ tabel --------- Ho ditolak

T hitung < tabel --------- Ho diterima

Selain dua uji tersebut juga dilihat indikator lain yaitu koefisien determinasi $\left(\mathrm{R}^{2}\right)$ yang menunjukan berapa besar pengaruh variabel bebas menentukan variabel terikat dengan menggunakan formula berikut:

$$
\mathrm{R}^{2}=\frac{\sum \mathrm{II}^{2}}{\sum \mathrm{YI}^{2}}
$$

\section{HASIL DAN PEMBAHASAN}

\section{Perkembangan belanja irigasi dan jaringan Kota Jambi}

Untuk mengetahui data dan perkembangan belanja irigasi dan jaringan Kota Jambi selama peruode tahun 2005 sampai tahun 2015 dapat dilihat pada tabel berikut ini:

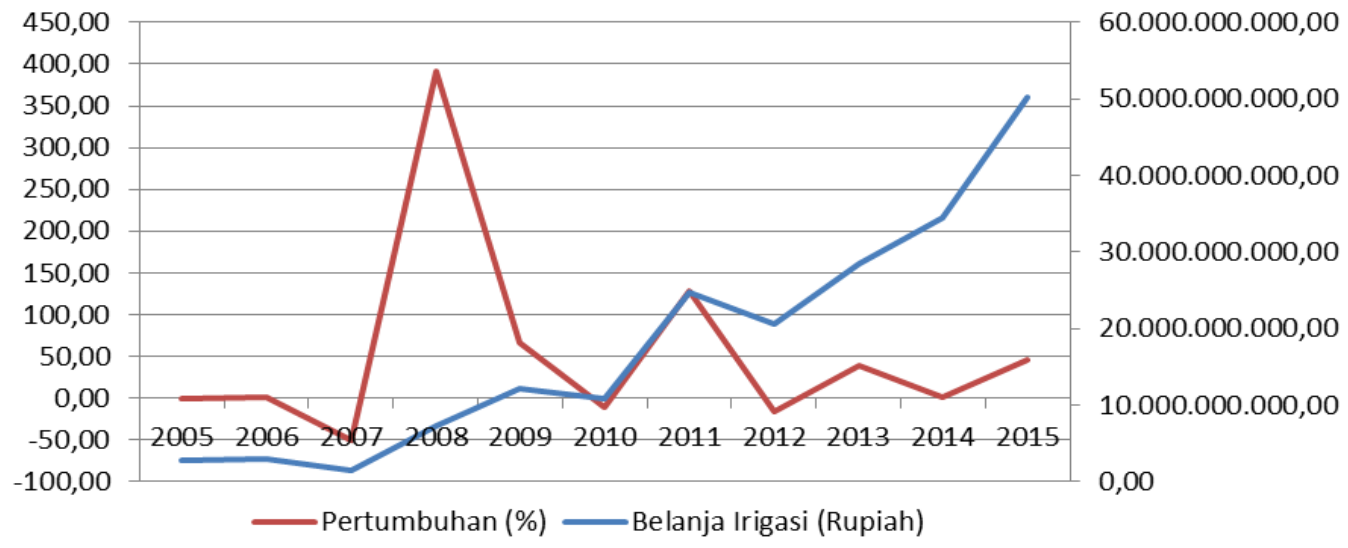

Sumber : BAPEDA Kota Jambi

Gambar 1 Perkembangan belanja irigasi dan jaringan Kota Jambi 
Dari Gambar.1 terlihat bahwa selama periode penelitian tahun 2005 sampai 2015 rata-rata nilai belanja irigasi dan jaringan Kota Jambi adalah 17.837.439.187,43 rupiah dengan rata-rata pertumbuhan $61,98 \%$, dari data juga di peroleh informasi pertumbuhan terendah terjadi pada tahun 2007 yakni $-50,47 \%$ dan pertumbuhan tertinggi terjadi pada tahun 2008 yakni sebesar 391,96\%.

\section{Perkembangan PDRB sektor pertanian Kota Jambi}

Untuk mengetahui data dan perkembangan PDRB sektor pertanian Kota Jambi atas dasar harga berlaku dapat dilihat pada tabel berikut ini :

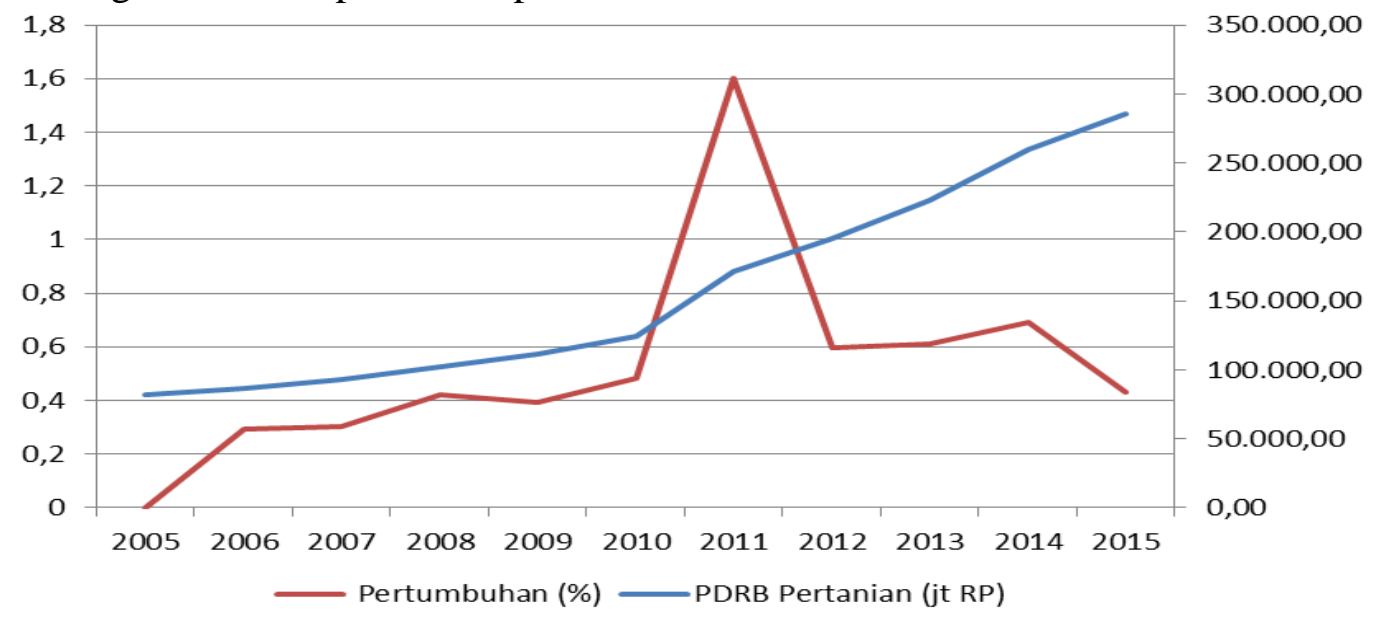

Sumber : BPS Kota Jambi

Gambar 2 Perkembangan PDRB Sektor pertanian Kota Jambi

Dari Gambar.2 dapat diperoleh informasi bahwa selama periode tahun 2005 sampai 2015 nilai rata-rata PDRB harga berlaku Kota Jambi sebesar 157.601,68 dalam juta rupiah dengan rata-rata pertumbuhan sebesar 13,67\% dan dari data diatas terlihat pertumbuhan PDRB harga berlaku Kota Jambi tertinggi pada tahun 2011 yakni 38,26\% dan pertumbuhan terendah terjadi pada tahun 2006 yakni $6,60 \%$.

\section{Pertumbuhan ekonomi Kota Jambi}

Untuk mengetahui data pertumbuhan ekonomi Kota Jambi yang di ambil dari kenaikan PDRB Harga berlaku dapat dilihat pada tabel berikut ini :

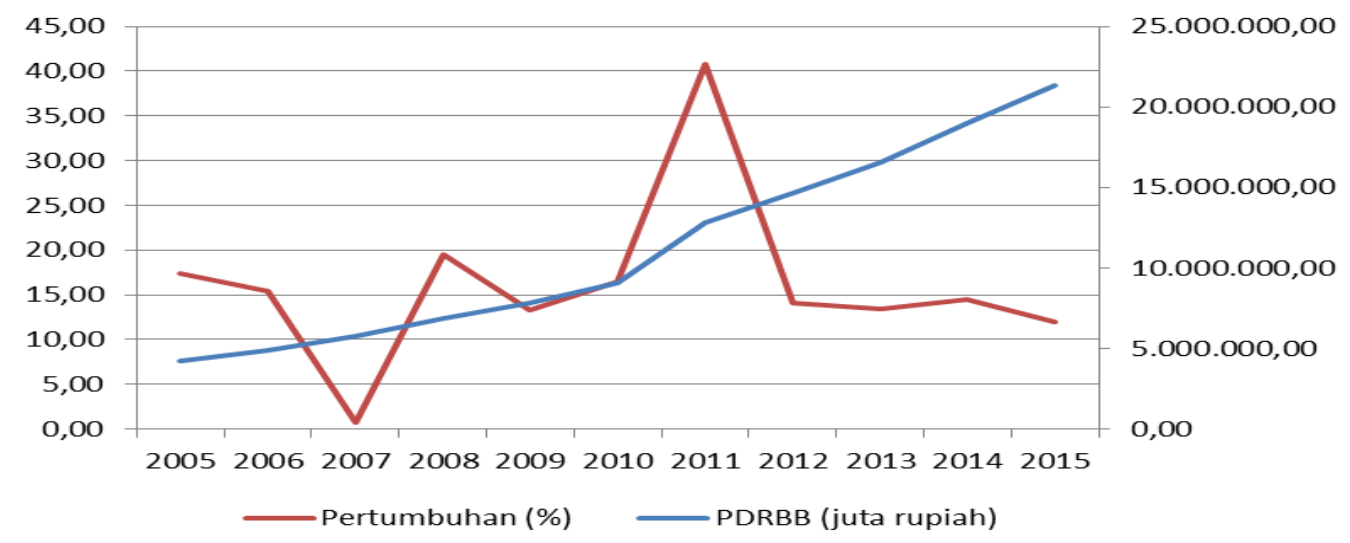

Sumber : BPS Kota Jambi

Gambar 3 Pertumbuhan ekonomi Kota Jambi atas dasar harga berlaku 
Dari Gambar.3 terlihat bahwa selama periode penelitian tahun 2005 sampai tahun 2007 rata-rata pertumbuhan ekonomi Kota Jambi adalah $17,70 \%$ dengan pertumbuhan tertinggi terjadi pada tahun 2011 yakni sebesar 40,72\% dan pertumbuhan terendah pada tahun 2015 yakni sebesar 12,3\%.

\section{Pengaruh belanja irigasi dan jaringan terhadap PDRB pertanian Kota Jambi}

Untuk mengetahui pengaruh belanja irigasi dan jaringan dapat dilihat pada tabel berikut ini :

Tabel 1 Hasil regresi belanja irigasi jaringan dan PDRB sektor pertanian

\begin{tabular}{lrllr}
\hline \multicolumn{1}{c}{ Variable } & Coefficient & Std. Error & t-Statistic & \multicolumn{1}{c}{ Prob. } \\
\multicolumn{1}{c}{ C } & 75366.11 & 8468.609 & 8.899468 & 0.0000 \\
\multicolumn{1}{c}{ BIJ } & $4.61 \mathrm{E}-06$ & $3.66 \mathrm{E}-07$ & 12.61311 & 0.0000 \\
\hline R-squared & 0.946457 & Mean dependent var & 157601.7 \\
Adjusted R-squared & 0.940508 & S.D. dependent var & 73489.54 \\
S.E. of regression & 17924.78 & Akaike info criterion & 22.58872 \\
Sum squared resid & $2.89 \mathrm{E}+09$ & Schwarz criterion & 22.66107 \\
Log likelihood & -122.2380 & F-statistic & 159.0905 \\
Durbin-Watson stat & 1.863282 & Prob(F-statistic) & 0.000001 \\
\hline
\end{tabular}

Sumber : Data diolah, 2017

Dari hasil regresi pada tabel diatas dapat diperoleh persamaan regresinya sebagai berikut :

\section{Pertanian $=75366.11048+4.61027941 \mathrm{e}-006 * \mathrm{BIJ}+\mathrm{e}$}

Dari persamaan Tabe. 1 tersebut dapat di interpretasikan bahwa pada saat belanja irigasi dan jaringan dalam posisi nol maka nilai PDRB pertanian adalah 75.366,11 dalam satuan juta rupiah dan jika belanja irigasi dan jaringan naik dalam satu satuan rupiah maka akan meningkatkan PDRB pertanian sebesar 0,00000046 dalam juta rupiah.

\section{Hasil uji t hitung}

Berdasarkan hasil regresi diperoleh nilai t hitung statistiknya sebesar 12,61 dengan probabilitas lebih kecil dari alpha $1 \%$ sehingga dapat disimpulkan bahwa secara statistik uji hipotesis menunjukkan bahwa variabel belanja irigasi dan jaringan berpengaruh positif dan signifikan terhadapa PDRB sektor pertanian.

\section{Pengaruh belanja irigasi dan jaringan terhadap pertumbuhan ekonomi}

Untuk mengetahui pengaruh belanja irigasi dan jaringan terhadap pertumbuhan ekonomi dapat dilihat pada tabel berikut ini :

Tabel 2 Hasil regresi belanja irigasi dan jaringan dengan pertumbuhan ekonomi

\begin{tabular}{lrlrr}
\hline \multicolumn{1}{c}{ Variable } & Coefficient & Std. Error & t-Statistic & \multicolumn{1}{c}{ Prob. } \\
\hline \multicolumn{1}{c}{ C } & 18.25343 & 3.949632 & 4.621553 & 0.0013 \\
\multicolumn{1}{c}{ BIJ } & $-3.09 \mathrm{E}-11$ & $1.70 \mathrm{E}-10$ & -0.181407 & 0.8601 \\
\hline R-squared & 0.003643 & Mean dependent var & 17.70182 \\
Adjusted R-squared & -0.107063 & S.D. dependent var & 7.945337 \\
S.E. of regression & 8.359850 & Akaike info criterion & 7.247724 \\
Sum squared resid & 628.9839 & Schwarz criterion & 7.320068 \\
Log likelihood & -37.86248 & F-statistic & 0.032909 \\
Durbin-Watson stat & 2.212070 & Prob(F-statistic) & 0.860068 \\
\hline
\end{tabular}

Sumber: Data diolah,2017 
Dari hasil regresi maka diperoleh persamaan:

$\mathrm{PE}=18.25343444$ - 3.092463297e-011*BIJ + e

Hasil Tabel. 2 belanja irigasi dan jaringan dalam satuan rupiah dengan pertumbuhan ekonomi pendekatan harga berlaku dalam satuan persen diperoleh persamaan regresi diatas yang dapat di interpretasikan yakni jika belanja irigasi dan jaringan nol maka pertumbuhan ekonomi sebesar 18,25\% dan jika belanaj irigasi dan jaringan naik 1 rupiah maka turun sebesar 0,000000000003 \% dengan asumsi nilai uji t statistik signfikan.

\section{Hasil uji t hitung}

Berdasarkan dari hasil regresi pada tabel 5.5. diatas diperoleh nilai t hitung statistik sebesar -0,18 dengan probabilitas 0,86 sehingga melebihi batas toleransi signifikansi alpha $10 \%$ sehingga dapat disimpulkan bahwa belanja irigasi dan jaringan tidak berpengaruh signifikan terhadap pertumbuhan ekonomi.

\section{KESIMPULAN DAN SARAN}

\section{Kesimpulan}

Selama periode penelitian tahun 2005 sampai 2015 rata-rata nilai belanja irigasi dan jaringan Kota Jambi adalah 17.837.439.187,43 rupiah dengan rata-rata pertumbuhan $61,98 \%$, dari data juga di peroleh informasi pertumbuhan terendah terjadi pada tahun 2007 yakni $-50,47 \%$ dan pertumbuhan tertinggi terjadi pada tahun 2008 yakni sebesar 391,96\%. nilai rata-rata PDRB harga berlaku Kota Jambi sebesar 157.601,68 dalam juta rupiah dengan rata-rata pertumbuhan sebesar 13,67\% dan dari data diatas terlihat pertumbuhan PDRB harga berlaku Kota Jambi tertinggi pada tahun 2011 yakni 38,26\% dan pertumbuhan terendah terjadi pada tahun 2006 yakni 6,60\%. rata-rata pertumbuhan ekonomi Kota Jambi adalah 17,70\% dengan pertumbuhan tertinggi terjadi pada tahun 2011 yakni sebesar 40,72\% dan pertumbuhan terendah pada tahun 2015 yakni sebesar 12,3\%. Berdasarkan hasil regresi diperoleh hasil bahwa pada model pertama belanja irigasi dan jaringan berpengaruh positif dan signifikan terhadap PDRB sektor pertanian sementara dan pada model kedua belanja irigasi dan jaringan tidak berpengaruh signifikan terhadap pertumbuhan ekonomi.

\section{Saran}

Pemerintah Kota Jambi sebaiknya tetap mempertimbangkan belanja irigasi dan jaringan dalam rencana belanja karena dapat meningkatkan sektor pertanian walaupun sektor ini bukan sektor unggulan Kota tapi diharapkan dapat dikembangkan sebagai sektor potensial. Untuk selanjutnya penelitian yang lebih panjang jangka waktunya untuk mengkaitkan pertumbuhan ekonomi dengan belanja irigasi dan jaringan dan dipertimbangkan menggunakan variabel harga konstan.

\section{DAFTAR PUSTAKA}

Agus Salim.(2005).Analisis Keterkaitan Antara Pengeluaran Pemerintah Pertumbuhan Ekonomi Ketimpangan Distribusi Pendapatan dan Kemiskinan di Indonesia 1976-2004, Disertasi Program Pascasarjana Unpad (tidak dipublikasikan).

Blanchard, Olivier.(2003). Macroeconomics.3rd Edition. Prentice-Hall. 
Bose,Niloy.;M.emranul,Haque.;Denise,R,Osborn,(2003).Public Expenditure and Economic Growth: A Dissaggregated Analysis For Developing Countries. Journal Compilation School of Economic Studies, 75(5); 533-566

Dornbusch, Rudiger.; Stanley Fischer.; Richard Startz.(2004). Macroeconomics. 9th Edition. McGraww-Hill.

Erfit.(2017).Pemanfaatan Dana Corporate Social Responsibility (CSR) Untuk Pembiayaan Pembangunan Pertanian di Provinsi Jambi. Jurnal Perspektif Pembiayaan dan Pembangunan Daerah, 4(3); 143-154.

Fan. S. Hazell.; S.Thorat. (1999). Linkages Between Government Spending,Growth, and Poverty in Rural India. American Agriculture Economic, 2(4); 1038-1051

Gaspersz, Vincent.(1997). Manajemen Kualitas Penerapan Konsep-Konsep Kualitas Dalam Manajemen Bisnis Total. PT. Gramedia Pustaka Utama: Jakarta.

Gujarati, Damodar N.(2004). Basic Econometrics. 4th Edition.

Gumilar Wijaksana.; Muhammad Safri.; Parmadi. (2017).Kontribusi dan Elastisitas Subsektor dalam Sektor Pertanian di Kabupaten Tebo. Jurnal Paradigma Ekonomika, 12(2); 77-86.

Jhingan, M.L. (1993). Ekonomi Pembangunan dan Perencanaan, Edisi ke-16, Penerbit Manajemen PT. Raja Grafindo Persada: Jakarta.

Mankiw, George N.(2001). Macroeconomics. 5th Edition. McGraw-Hill.

McGraw-Hill. (2008). International Financial Statistics. CD-ROM. IMF.

NN.(2013). Badan Pusat Statistik Kota Jambi. Jambi dalam Angkat Tahun 2013:Jambi.

NN.(2013). Badan Pusat Statistik Kota Jambi. Kota Jambi dalam Angka Tahun 2013: Jambi.

NN.(2014). Badan Pusat Statistik Kota Jambi. Kota Jambi dalam Angka Tahun 2014: Jambi

NN.(2014.) Badan Pusat Statistik Kota Jambi. Jambi dalam Angkat Tahun 2014:Jambi.

NN.(2015). Badan Pusat Statistik Kota Jambi. Jambi dalam Angkat Tahun 2015:Jambi.

NN.(2015). Badan Pusat Statistik Kota Jambi. Kota Jambi dalam Angka Tahun 2015: Jambi

Suparmoko.(2001). Ekonomi Publik Untuk Keuangan dan Pembangunan Daerah, BPFE, Yogyakarta.

Syaifuddin..;Adi,Bhakti.; Rahma,Nurjanah.(2017).Dampak Peningkatan Pengeluaran Konsumsi Sektor Rumah Tangga Dan Pengeluaran Sektor Pemerintah Terhadap Pertumbuhan Ekonomi Di Propinsi Jambi. Jurnal Sains Sosio Humaniora, 1(1); 66-78

Terukazu suruga.; Manh vu le.(2005).The effects FDI and Public Expenditure on Economic Growth: From theoretical model to Empirical Evidence,Kobe University, No.2 Tahun 2005; 1-10 